Article

\title{
Green Social Responsibility and Company Financing Cost-Based on Empirical Studies of Listed Companies in China
}

\author{
Duan Ji ${ }^{1}$, Yuyu Liu ${ }^{1}$, Lin Zhang ${ }^{2,3, *}$, Jingjing An ${ }^{4, *}$ and Wenyan Sun ${ }^{5}$ \\ 1 School of Accounting, Shandong University of Finance and Economics, Ji'nan 250014, Shandong, China; \\ 20174543@sdufe.edu.cn (D.J.); 20188181@sdufe.edu.cn (Y.L.) \\ 2 School of Law and Economics, Shandong University of Technology, Zibo 255000, Shandong, China \\ 3 School of Law, Fujian Normal University, Fuzhou 350117, Fujian, China \\ 4 School of Law, Shandong University of Technology, Zibo 255000, Shandong, China \\ 5 Agricultural Bank of China, Qingdao 266000, Shandong, China; sunwenyankr@abchina.com \\ * Correspondence: linzhang@sdut.edu.cn (L.Z.); anjingjing@sdut.edu.cn (J.A.)
}

Received: 30 June 2020; Accepted: 31 July 2020; Published: 3 August 2020

\begin{abstract}
Taking Chinese A-share listed companies in Shanghai and Shenzhen Stock Exchanges from 2007 to 2018 as research samples, this paper studies the relationship between green corporation social responsibility (CSR) and financing cost of Chinese companies by means of moderating effect and multiple regression analysis. It is found that, for companies, the better the performance of green social responsibility, the lower the financing cost. However, it is also found that for companies with different pollution degrees and natures of property rights, the financing cost reduction effects due to green social responsibility are quite different. Compared with low-polluting companies, the financing cost reduction effect arisen by green CSR will be weakened for high-polluting companies. Compared with private companies, the financing cost reduction effect from green CSR will also be weakened for state-owned companies. To sum up, the research results of this paper show that there is a significant saving effect on financing cost for companies undertaking green CSR, and companies' characteristics of pollution degree and property right can regulate the impact of green CSR on financing cost. The conclusion of this paper can encourage companies to take green social responsibility actively and reduce the cost of financing.
\end{abstract}

Keywords: green corporation social responsibility (CSR); cost of financing; nature of property rights; high-polluting company

\section{The Introduction}

In the past 20 years, corporation social responsibility (CSR) has become an increasingly important topic, and companies are required to take more and more social responsibility gradually [1]. However, the fulfillment of social responsibility often exceeded the companies' short-term interests [2]. Therefore, undertaking social responsibility has become a voluntary activity of companies to satisfy different stakeholders [3], which also build the foundation and become the source of companies' long-term development. In reality, on the one hand, with the rapid development of the economy, serious damage to the environment has been caused by the production and operation activities of many companies, and many of them even pursue high short-term returns with the sacrifice of ecological systems. On the other hand, as the government attaches increasing importance to environmental issues and becomes stricter in environmental regulation, more and more companies include environmental protection in their company social responsibility [4], which directly gives rise to the new concept of "green company social responsibility." 
The green social responsibility of an enterprise refers to seeking green or renewable resources (such as solar energy) that can be replaced while pursuing profit maximization, so as to reduce energy consumption, protect the ecological environment, and ensure product safety to a certain extent [5-7]. Green company social responsibility is actually an important and different aspect of company social responsibility [8]. However, there are different opinions on whether green company social responsibility should be regarded as legal responsibility or moral responsibility. Since there is no specific requirement in the current Company Law of China, it only states in Article 5 that, "In conducting its business operations, a company shall abide by laws and administrative regulations, observe social ethics and business ethics, act in good faith, accept the supervision of the government and the general public, and bear social responsibility." Therefore, some scholars believe that the green social responsibility undertaken by companies is only a moral obligation rather than a legally mandatory requirement [9]. According to the current status of ecological protection and green social responsibility development in China, companies generally lack awareness of green social responsibility, and the capability to fulfill their responsibilities as well, along with low external social pressure and insufficient government supervision [10], the fulfillment of companies' green social responsibilities still needs to be improved and strengthened. Therefore, the lack of external supervision and enforcement mechanism is bound to be the main reason of the weak awareness of green social responsibility of Chinese companies. However, the internal driving forces of companies can also play a significant or even crucial role in urging them to undertake green social responsibility. This paper argues that it is a more effective way to encourage companies to take green social responsibility. As far as the current situation of companies is concerned, most companies, especially small-and-medium-sized companies, are faced with the dilemma of high financing costs [11]. In this paper, by constructing the logical relationship between green social responsibility fulfillment and company financing cost, the author attempts to answer the following two questions. The first is whether the green social responsibility of companies can influence the financing cost. The second is that, if the influence exists, whether there are differences among those companies with different property rights and pollution degree. By solving the above two problems, it is helpful for us to find the internal driving force for companies to fulfill their green social responsibility, thus encouraging companies to take green social responsibility so as to realize the sustainable development of the economy and society and achieve the goal of the harmonious coexistence of human beings and the environment.

In recent years, the Chinese government has attached great importance to the concept of green development and has adhered to the path of high-quality development. While pursuing economic benefits, Chinese companies are also paying more and more attention to implementing green development strategy and taking responsibility for green development, hoping to improve environmental benefits. Taking listed companies in China as samples, this paper studies the relationship between green CSR and company financing cost. It has the following two advantages: (1) the development of green CSR in Chinese companies is obviously in a rising stage and has made great progress both in theory and in practice. Therefore, obtaining relevant data from Chinese companies to study green CSR and financing cost can more effectively verify whether there is a direct link between them. (2) China's state-owned companies and private companies have significant differences in nature, source of financing, and financing costs. Therefore, data on Chinese companies can more accurately reveal that, under different property rights, the effect of green CSR on financing cost is different. However, there are not many domestic and foreign studies on whether companies can reduce their financing costs by actively fulfilling their green social responsibility. Therefore, based on the relevant data of China's listed companies, this paper mainly completes two empirical tests: the first is to test whether companies actively undertaking green social responsibility can reduce their financing cost; and the second is, with the impact of green social responsibility, whether the cost of financing is different for companies with different natures. On the basis of the above studies, this paper takes Chinese A-share listed companies in the Shanghai and Shenzhen Stock Exchanges from 2007 to 2018 as research samples and mainly draws the following conclusions through the methods of moderating effect and 
multiple regression analysis: (1) The companies' active fulfillment of green social responsibility can reduce financing cost to a certain extent. The better the performance of green CSR, the greater the reduction of financing cost. In general, companies actively fulfilling their green social responsibility can reduce the cost of financing, while environment penalties will increase the cost of financing. (2) Different pollution levels and property rights of companies will affect green social responsibility's saving effect on financing cost. Compared with low-polluting companies, high-polluting companies have lower saving effect of financing cost for green CSR, while state-owned companies have a lower saving effect on the financing cost of green CSR compared with private companies.

The contributions of the research and innovation of this article mainly lie in the following aspects: (1) This paper seeks to creatively build the relationship between green CSR and company financing cost, not only theoretically develop and rich green CSR literature related to the cost of financing, but also practically find internal driving force for companies to undertake green CSR and provide the approaches and methodologies to reduce their financing cost. (2) After testing the saving effect of green CSR on the financing cost of companies, this paper further verifies the difference of the sensitivity of the financing cost of high-polluting and low-polluting companies and state-owned and private companies to green CSR through the moderating effect. In other words, compared with low-polluting companies, high-polluting companies will have a weaker saving effect on financing cost of green CSR due to their high pollution characteristics and external pressure such as environmental regulation. Compared with private companies, state-owned companies will have a weaker saving effect on financing cost of green CSR due to property right differences and soft budget constraints.

\section{Literature Review and Research Hypothesis}

\subsection{Literature Review}

Today, for companies in the era of the knowledge economy, it is undoubtedly imperative to restate a new understanding of the use of environmental resources [12]. Up to now, society has widely raised concerns regarding company green CSR, which is undoubtedly closely related to the establishment of the concept of sustainable development [9]. Some scholars also believe that green corporate social responsibility (GCSR) is the result of the deficiency and management analysis of the water, energy, and food network (WEF)) [13].The green social responsibility of an enterprise refers to seeking green or renewable resources (such as solar energy) that can be replaced while pursuing profit maximization in order to reduce energy consumption, protect the ecological environment, and ensure product safety to a certain extent [5-7].

"Academic scholars focus on the fulfillment of companies' green social responsibility. It is believed that good enterprise environmental practice will bring advantages $[14,15]$. First of all, in terms of internal motivation, scholars have confirmed the positive impact of companies' fulfillment of green social responsibility from such dimensions as establishing company image [16], improving market competitiveness [17], and enhancing company innovation ability [18]. On the one hand, companies focusing on green responsibility can more easily obtain intangible resources to promote innovation, thus improving innovation performance [18]. On the other hand, the undertaking of green social responsibility not only meets the consumers' requirements and improves the company image [16] but also helps to improve the market share [17]. In terms of external pressure, due to market pressure, ownership pressure, social pressure, and regulatory pressure, enterprises attach importance to environmental performance or environmental practice [19]. Therefore, companies should take the construction of company image on green social responsibility as their long-term strategic goal from the perspective of strategic management and promote the implementation of green social responsibility through policy design [16]. For example, some scholars have concluded that TQM can significantly improve the ability of organizations to achieve green performance goals and has a significant positive impact on the performance of corporate social responsibility [20]. Second, companies' undertaking of green social responsibility is an extension of the theory of company social responsibility in the field of 
environmental protection [21]. Corporate environmental performance is considered to be an important part of corporate social responsibility structure [22], which mean that green social responsibility is actually an important and unique aspect of company social responsibility [8]. Driven by the widely reported corporate environment and social scandals, managers and shareholders are now showing greater interest in the concept of corporate social responsibility [22]. At present, in the academy, there is in-depth research on CSR undertaking, which has gradually constructed the relationship with consumer behavior [23], financial risk [24], and investor sentiment [25]. Green and others believe that because corporate social responsibility behavior is related to consumers' own interests, consumers will perceive the value of corporate social responsibility through one of three forms-emotion, society, and function. Lindblom [26] believed that the fulfillment of company social responsibility and the disclosure of social responsibility information have strategic purposes and can be regarded as a strategic behavior of companies. Dhaliwal et al. [24] used company data from 31 countries to test the relationship between non-financial information disclosure and the accuracy of analyst predictions and found that, in stakeholder-oriented countries, CSR performance is more likely to affect company financial performance. Pierre Chollet et al. [27] stated that a firm's good social responsibility and governance performance can reduce financial risks and enable the firm to fulfill its commitment to good environmental practices. James P. Naughton et al. [25] argued that investor sentiment plays such a role in CSR commitments that announcements of CSR activities produced positive above-expectation returns when investors have a premium on valuating CSR performance. The above studies also have important implications for building the relationship between green social responsibility and company finance.

Domestic and foreign scholars' research on financing cost is mainly divided into internal factors [28-30] and external factors [31,32]. From the perspective of internal factors, early studies focused on the relationship between financial information and financing cost, such as company scale, debt level, liquidity, profitability, etc. [33], then turned to the quality and disclosure of accounting information. The study found that the lower the quality of company earnings, the higher the loan interest rate and the stricter the additional terms [34], and there was a remarkable negative correlation between the quality of company information disclosure and the cost of financing $[28,29]$. It is worth noting that there is a positive correlation between financing cost and carbon emission risk of companies that fail to respond to disclosure of carbon project [35] and a negative correlation with carbon information disclosure level [36]. In addition, the views of shareholders and stakeholders are often separated, so agency costs and agency problems may arise [37], and financing costs can reduce agency costs between management, shareholders and creditors and also solve agency problems between shareholders and creditors [38]. These are directly proportional to company governance structure [38,39] and independence of the board of directors [30]. In terms of external factors, the study found that company social performance was positively correlated with credit rating, and company social performance had a positive effect on reducing financing capital cost [31]. The potential litigation risk will affect the future uncertainty on the operation of company, thus increasing the future liquidity risk of the company, and the liquidity risk will affect the financing structure and financing cost [40-42]. The better the external audit quality, the lower the financing cost [32].

Although there are few domestic and abroad studies on the relationship between green CSR and company financing cost, it can be inferred from the literature that, on the one hand, the study of relationship between company social responsibility and the financing costs of research has been relatively mature, and green CSR is an important part of social responsibility, as they have many similarities. On the other hand, many domestic and foreign scholars have studied the relationship between financing cost and other relevant factors, such as carbon emission disclosure level, social performance, and innovation performance, are closely related to green CSR. Therefore, to sum up, it is feasible and reasonable to study the relationship between green CSR and company financing cost in this paper. 


\subsection{Green CSR and Company Financing Cost}

From perspective of principal-agent theory, signal transmission theory and environmental regulation theory, this paper will analyze the impact of green responsibility on financing cost. First of all, since a large amount of carbon gas emitted by companies is an important cause of environmental pollution, carbon emission and its disclosure are the key benchmark to reflect companies' green CSR performance. When the creditor and the company's goal and opinion are different on the fulfilment of green social responsibility, the problem of agency arises [43]. When the fulfillment of green social company responsibility is not fully disclosed, investors will spend more cost to collect relevant information, eventually increasing the company's financing cost [44]. Second, green company social responsibility sends a positive signal to the market and can reduce the mismatching of resources for creditors, such as banks [43]. Their search clearly shows that, for those companies who do not disclose the carbon information, its carbon risk is significantly positively correlated with financing cost [35], and the level of carbon information disclosure is negatively correlated with financing cost [36]. At the same time, with the enhancement of environmental regulations, companies undertaking green social responsibility will reduce the risk of environmental punishment and reduce agency cost through timely disclosure of green responsibility information, so that the market will reduce the financing cost required by companies, as well as reward the companies undertaking green responsibility. In addition, the increase of CSR commitment is regarded as a signal of good performance and improvement of the relationship between the company and its key stakeholders, which may have an impact on the financial performance indicators [27]. Finally, China is paying more and more attention to environmental issues, and environmental regulations are becoming more and more stringent. In 2007, the Chinese government launched the "green credit" policy, so companies' commitment to green social responsibility will have a direct and positive impact on financing activities. Furthermore, green social responsibility is an important part of company social responsibility, and company social responsibility also plays a positive role on decreasing the cost of financing [31]. Company social responsibility commitment can assume that the financial risk is reduced, reflecting in lower marginal financing cost, lower financing cost [35], or ease in obtaining financing [31], while negative company social responsibility can increase the cost of financing [45].

To sum up, this paper believes that the company's green CSR can reduce the cost of company financing. Positive green CSR can enhance investors' trust and confidence in the company, so the required risk premium will be lower, and thus, the company's financing cost will be reduced. Negative green CSR causes public dissatisfaction due to its environmental damage and environmental penalty, which leads to the increase of company financing cost due to limited financing channels and increases the risks taken by investors. The net value of green CSR comprehensively considers the situation of green CSR and can also reduce the financing cost of companies.

H1. Companies undertaking green social responsibility can significantly reduce the cost of financing.

\subsection{High-Polluting Companies, Green CSR, and Company Financing Cost}

Compared with low-polluting companies, high-polluting companies should more actively undertake green CSR in order to rapidly reduce China's carbon emissions and other related indicators and achieve significant results in environmental protection. Due to the unique nature of high-polluting companies and the influence of external factors, the saving effect of green CSR will reduce high-polluting companies' financing cost. On the one hand, companies with high pollution have a higher carbon risk and are subject to greater regulatory pressure from environmental protection authorities and are more likely to incur potential compliance costs and lawsuits, so the risk of default on financing is higher [46]. On the other hand, during the credit review process, banks check the operation performance of the company but also take the environmental protection index into account and add the fulfillment of the responsibility of environmental protection of the company in the review system [47]. In addition, in accordance with national industrial policy, financial institutions have to raise interest rates, limit scale 
of loans to increase the "high pollution, high energy, overcapacity" companies' financing costs so as to force the companies to upgrade production technology innovation and reduce pollution to the environment [48]. Therefore, even if a high-polluting company takes on green CSR, banks will still it with provide a higher financing cost than a low-polluting company.

H2. Compared with low-polluting companies, high-polluting companies have a weakened saving effect of green CSR on financing cost.

\subsection{State-Owned Companies, Green CSR, and Company Financing Cost}

Compared with private companies, state-owned companies have significantly different characteristics in green CSR and credit financing. On the one hand, China's state-owned companies have had a close relationship with the government since their foundations. In terms of specific operation mechanisms, there is a command-control relationship between the government and state-owned companies, and the government has a direct influence on the operation of state-owned companies. The development trend of state-owned companies represents the orientation of national policies to a large extent. At the same time, the relationship between the political environment and corporate social responsibility is very important, and the political orientation of corporate board also plays a role in corporate social responsibility [49]. Therefore, compared with private companies, public figures have higher expectations on state-owned companies, believing that they should set an example and actively undertake green CSR to implement relevant national policies. On the other hand, state-owned companies, due to their particularity in nature, have political background and certain social functions, more likely to get support from the government in terms of policies, taxes and financing. Many domestic and foreign scholars have opinions on whether political connection helps to obtain financing convenience [50-52]. Moreover, when state-owned companies have losses or are even on the edge of bankruptcy, the government will help them out of difficulties by injecting financing at a low cost [53]. Therefore, state-owned companies have a lower cost of financing. To sum up, compared with private companies, the saving effect of green CSR on financing cost is not so obvious in state-owned companies.

H3. Compared with private companies, state-owned companies have a weakened saving effect of green CSR on financing cost.

\section{The Research Design}

\subsection{The Sample and Data}

According to the research purpose of this paper, Chinese A-share listed companies in Shanghai and Shenzhen Stock Exchanges from 2007 to 2018 will be regarded as research samples, excluding special treatment (ST) and data-deficient companies; thus, a total of 5360 company samples are obtained. Green CSR data are measured by three dimensions: positive green CSR (Env), negative green CSR (Env_con), and net value of green CSR (dEnv). Data are collected manually.

Compared with general companies, high-polluting companies pay more attention to the issue of green CSR. Therefore, the sample is further subdivided based on whether it is a high-pollution industry. According to the documents adopted by the Environmental Protection Department, "the Industry Classification Management Catalog of Listed Companies in Environmental Protection ([2008] No. 373)", this paper regards the thermal power, steel, cement, electrolytic aluminum, coal, metallurgy, building materials, mining, chemical, petrochemical, pharmaceutical, light (brewing, papermaking, fermentation), textile, leather industries as "high pollution, high energy" industries. According to the industry code listed in the above regulation, the CSMAR database is used to label the listed companies. The research samples of high-polluting companies are obtained by excluding companies that did not exist during 2007-2017 and the companies whose industry codes changed and 
were not among the eight highest-pollution industries listed in the "Quarterly Update of Industry Classification of Listed Companies" issued by the China Securities Regulatory Commission. The rest of the study data are obtained mainly from the CSMAR database. After excluding companies lacking necessary variables, there were 875 listed companies and 5360 observations from 2007 to 2018. In order to eliminate the influence of outliers, this paper winsorizes all continuous variables of the model at the upper and lower limit of $1 \%$.

\subsection{Models and Variable Definitions}

Variable green CSR is explained by positive green CSR (Env), negative green CSR (Env-con) and net value of the green CSR (dEnv) in three dimensions. The positive green CSR (Env) include eight parts, such as (1) whether the firm produces environmentally friendly products; (2) whether the firm has adopted environmentally friendly policies such as developing technology to reduce wasteful emissions of gas, water, residues, or greenhouse gases; (3) whether the firm has adopted policies or regulations encouraging the use of renewable energy and participation in the circular economy; (4) whether the firm has policies or techniques to save energy; (5) whether the firm has green office policies; (6) whether the firm's environmental management system is certified by the International Organization of Standardization (ISO) 14001 standard; (7) whether the firm has received environmental recognition or other positive reviews; and (8) other aspects of the firm's environmental presence not covered in the other indicators. The variable will be 1 if there are positive green CSR actions, otherwise it will be 0. Env is the sum of all project scores [54]. Negative green CSR (Env_con) refers to the negative green social responsibility behavior of companies in environmental penalty and pollutant discharge. If there is such behavior, the variable is 1, and otherwise 0. Env_con is the sum of the scores for these two items. Net value of green CSR behavior (dEnv) is the difference between Env and Env_con.

COD is the dependent variable. According to the calculation method of Zou and Adams (2006), COD $=$ interest expense * 100/ (initial debt + ending debt) /2.Size, ROA, First, Ind, Dual, and Age are the control variables, where Size is the natural logarithm of the total ending assets, ROA is the return on assets, First is the shareholding ratio of the largest shareholder, Ind is the proportion of the number of independent directors in the board of directors, Dual is whether the chairman and the general manager are the same person, and Age is the company's existing period. Year refers to the year effect; Firm refers to individual fixed effect, and $\varepsilon$ is random disturbance term. The meanings of the main variables are shown in Table 1.

Therefore, the model in this paper is shown as follows: Models 1-3 test hypothesis 1; Models 4-6 test hypotheses 2; and Models 7-9 test hypothesis 3. For hypothesis 1, we expected that both positive green CSR (Env) and net value of green CSR (dEnv) could significantly reduce COD, that is, the coefficient is significantly negatively correlated. However, negative green CSR (Env-con) can significantly improve COD, that is, the coefficient is significantly positive correlation.

Model $1 \mathrm{COD}=\mathrm{Env}+$ Size $+\mathrm{Lev}+\mathrm{ROA}+$ First + Ind + Dual + Age $+\varepsilon$

Model 2 COD $=$ Env_con + Size + Lev + ROA + First + Ind + Dual + Age $+\varepsilon$

Model $3 \mathrm{COD}=\mathrm{dEnv}+$ Size + Lev + ROA + First + Ind + Dual + Age $+\varepsilon$

Model 4 COD $=$ Env + High + Env ${ }^{*}$ High + Size + Lev + ROA + First + Ind + Dual + Age $+\varepsilon$

Model 5 COD $=$ Env_con + High + Env-con ${ }^{*}$ High + Size + Lev + ROA + First + Ind + Dual + Age $+\varepsilon$

Model $6 \mathrm{COD}=\mathrm{dEnv}+\mathrm{High}+\mathrm{dEnv}{ }^{*} \mathrm{High}+\mathrm{Size}+\mathrm{Lev}+\mathrm{ROA}+$ First + Ind + Dual + Age $+\varepsilon$

Model $7 \mathrm{COD}=\mathrm{Env}+\mathrm{Soe}+\mathrm{Env} * \mathrm{Soe}+\mathrm{Size}+\mathrm{Lev}+\mathrm{ROA}+$ First + Ind + Dual + Age $+\varepsilon$

Model 8 COD $=$ Env_con + Soe + Env-con $*$ Soe + Size + Lev + ROA + First + Ind + Dual + Age $+\varepsilon$

Model $9 \mathrm{COD}=\mathrm{dEnv}+\mathrm{Soe}+\mathrm{dEnv} *$ Soe + Size $+\mathrm{Lev}+\mathrm{ROA}+$ First + Ind + Dual + Age $+\varepsilon$ 
Table 1. Variable definition table.

\begin{tabular}{|c|c|}
\hline Variable Name & Definition \\
\hline COD & Interest expense ${ }^{*} 100 /($ initial debt + ending debt)/2 \\
\hline Env & $\begin{array}{l}\text { The Env is composed of eight parts which are mentioned in the Section } 3.2 \text {. } \\
\text { The variable will be } 1 \text { if there is a positive green corporation social responsibility } \\
\text { (CSR) action, otherwise } 0 \text {. Env is the sum of all project scores. }\end{array}$ \\
\hline Env_con & $\begin{array}{l}\text { Negative green social responsibility behavior of companies in environmental } \\
\text { penalty and pollutant discharge. If there is such behavior, the variable is } 1 \text {, } \\
\text { otherwise } 0 \text {. Env_con is the sum of the scores for these two items. }\end{array}$ \\
\hline dEnv & The difference between Env and Env_con \\
\hline The Size & The natural logarithm of the total ending assets \\
\hline Roa & Return on assets \\
\hline Lev & Leverage is measured as total non-current debt divided by year-end total assets. \\
\hline First & Shareholding ratio of the largest shareholder \\
\hline Ind & $\begin{array}{l}\text { The proportion of the number of independent directors in the board of directors } \\
\qquad(\mathrm{BOD})=\text { number of independent directors/number of BOD }\end{array}$ \\
\hline Dual & Two positions, 1 for the same person, 0 for different person. \\
\hline Age & Years of establishment \\
\hline
\end{tabular}

\section{The Results}

\subsection{Descriptive Statistics}

Table 2 illustrates descriptive statistics of green CSR and COD, which are the main variables studied in this paper.

Table 2. Descriptive statistics of major variables.

\begin{tabular}{ccccccccc}
\hline Variable & $\mathbf{N}$ & Mean & sd & Min & p25 & p50 & p75 & Max \\
\hline COD & 5360 & 2.229 & 1.486 & 0 & 0.969 & 2.132 & 3.326 & 5.758 \\
Env & 5360 & 2.872 & 1.606 & 0 & 2 & 3 & 4 & 7 \\
Env_con & 5360 & 0.199 & 0.416 & 0 & 0 & 0 & 0 & 2 \\
dEnv & 5360 & 2.679 & 1.592 & 0 & 1 & 3 & 4 & 7 \\
size & 5360 & 22.84 & 1.317 & 20.20 & 21.91 & 22.72 & 23.67 & 28.07 \\
roa & 5360 & 0.048 & 0.054 & -0.134 & 0.018 & 0.040 & 0.073 & 0.232 \\
lev & 5360 & 0.486 & 0.197 & 0.069 & 0.336 & 0.496 & 0.638 & 0.942 \\
first & 5360 & 37.26 & 16.04 & 7.840 & 24.13 & 36.06 & 49.34 & 75.84 \\
indp & 5360 & 0.372 & 0.054 & 0.300 & 0.333 & 0.353 & 0.400 & 0.571 \\
dual & 5360 & 0.181 & 0.385 & 0 & 0 & 0 & 0 & 1 \\
age & 5360 & 16.05 & 5.463 & 3 & 12 & 16 & 20 & 30 \\
\hline
\end{tabular}

According to Table 2, in the research samples, the average financing cost of company is 2.229, the highest is 5.758, the minimum is 0 , and the median is about 2.132. For green CSR indicators, positive green CSR (Env)'s average is 2.872, the median is 3, the maximum is 7, and the minimum is 0 . The negative green CSR (Env_con)'s average is 0.199 , the median is 0 , the maximum is 2 , and the minimum 0 . The net value of green CSR (dEnv) considers the positive green CSR (Env) and the negative green CSR(Env_con), with the mean is 2.679 , the maximum is 7 , and the minimum is 0 . The analysis of the distribution of these three indicators can also show that the performance of green CSR of listed companies in China is relatively optimistic. The average proportion of independent directors in the sample companies is about 0.372 , which is also in line with the actual company governance situation in China. China requires the proportion of independent directors to be $1 / 3$ of the number of the board 
of directors. It can also be found that the average age of the sample companies is 16.050; the Roa's average is 0.048 , and the Size is 22.84 .

\subsection{Empirical Results and Analysis}

To test the impact of green CSR on company financing costs, this paper divides green CSR into the following three dimensions: positive green social responsibility behavior (Env), negative green social responsibility behavior (Env_con) and net value of green social responsibility behavior (dEnv). In Table 3, according to the main regression analysis, three indicators have a direct regression against the cost of financing (COD), although the company's positive green social responsibility behavior (Env) has no significant impact on the cost of financing, the other two indicators support the hypothesis of hypothesis 1 in this paper. When there is a negative green social responsibility behavior in the company (Env_con), namely when the company has environment penalties and pollutant emissions, under the condition of the $1 \%$ level, the cost of company financing significantly increases, with a coefficient as high as 0.394 . When considering the green CSR behavior of companies comprehensively, it is found that the net value of green CSR behavior (dEnv) can significantly reduce the financing cost of companies. This can also explain that, on the one hand, a multi-dimensional measurement method should be used to measure companies' green CSR behavior, and a single indicator as positive or negative green CSR behaviors cannot comprehensively summarize companies' green CSR. On the other hand, it can be found that negative green social responsibility behaviors may have a more prominent impact on the cost of company financing. Therefore, the results in Table 3 verify hypothesis 1 in this paper.

Table 3. Impact of green social responsibility on company financing cost.

\begin{tabular}{|c|c|c|c|}
\hline & (1) COD & (2) COD & (3) COD \\
\hline Env & $\begin{array}{c}0.003 \\
(0.244)\end{array}$ & & \\
\hline Env_con & & $\begin{array}{c}0.394^{* * *} \\
(8.230)\end{array}$ & \\
\hline $\mathrm{dEnv}$ & & & $\begin{array}{l}-0.019 * \\
(-1.697)\end{array}$ \\
\hline size & $\begin{array}{c}-0.043^{* *} \\
(-2.421)\end{array}$ & $\begin{array}{c}-0.053^{* * *} \\
(-3.064)\end{array}$ & $\begin{array}{c}-0.036 \text { ** } \\
(-2.018)\end{array}$ \\
\hline lev & $\begin{array}{l}2.213^{* * *} \\
(16.502)\end{array}$ & $\begin{array}{l}2.173^{* * *} \\
(16.245)\end{array}$ & $\begin{array}{c}2.208^{* * *} \\
(16.460)\end{array}$ \\
\hline roa & $\begin{array}{c}-5.803^{* * *} \\
(-14.740)\end{array}$ & $\begin{array}{l}-5.541 * * * \\
(-14.095)\end{array}$ & $\begin{array}{c}-5.782 * * * \\
(-14.676)\end{array}$ \\
\hline first & $\begin{array}{c}-0.009 * * * \\
(-7.049)\end{array}$ & $\begin{array}{c}-0.009 * * * \\
(-7.120)\end{array}$ & $\begin{array}{c}-0.009^{* * *} \\
(-7.034)\end{array}$ \\
\hline indp & $\begin{array}{l}0.611 * \\
(1.896)\end{array}$ & $\begin{array}{c}0.687^{* *} \\
(2.128)\end{array}$ & $\begin{array}{l}0.595^{*} \\
(1.848)\end{array}$ \\
\hline dual & $\begin{array}{c}0.245^{* * *} \\
(5.135)\end{array}$ & $\begin{array}{c}0.254^{* * *} \\
(5.287)\end{array}$ & $\begin{array}{c}0.244^{* * *} \\
(5.111)\end{array}$ \\
\hline age & $\begin{array}{c}0.006 \\
(1.602)\end{array}$ & $\begin{array}{l}0.007^{*} \\
(1.827)\end{array}$ & $\begin{array}{l}0.006^{*} \\
(1.667)\end{array}$ \\
\hline Industry fixed effects & $\mathrm{Y}$ & $\mathrm{Y}$ & $\mathrm{Y}$ \\
\hline Year fixed effects & $\mathrm{Y}$ & $\mathrm{Y}$ & Y \\
\hline _cons & $\begin{array}{c}3.347^{* * *} \\
(5.292)\end{array}$ & $\begin{array}{c}3.550 * * * \\
(5.799)\end{array}$ & $\begin{array}{c}3.220 * * * \\
(5.125)\end{array}$ \\
\hline$N$ & 5360 & 5360 & 5360 \\
\hline r2_a & 0.279 & 0.288 & 0.279 \\
\hline $\bar{F}$ & 71.193 & 74.386 & 71.078 \\
\hline
\end{tabular}

\subsection{Empirical Results and Analysis: The Moderating Effects of High-Pollution Industries}

From the three models in Table 4, we can find that the coefficient of the High variable is positively correlated with COD at the significance level of $1 \%$, which can also indicate that the financing cost of Chinese companies with high pollution is high. However, with the strong support of the Chinese government for environmental protection, a series of policies and subsidies (such as green credit) have been introduced to support the green development of companies, which has a direct impact 
on high-polluting companies. Therefore, when high-polluting companies undertake more green CSR behaviors, the financing cost of companies will be significantly reduced. In Table 4, both Env and dEnv confirm this opinion. However, according to Table 4 and Model 2, the negative green CSR behavior (Env_con) and COD have no significant correlation, because affected by the nature of the industry, the probability of pollution companies' punishment is higher than other industries. When the public recognizes a particular industry or company as "high pollution/high-polluting", they are more tolerant of environment punishment and pollutant emission. More scholars also found before that, taking China's high pollution listed companies in metallurgy, the chemical industry, and the oil industry as a sample, through the correlation regression verification of environmental indicators and stock price changes from 2007 to 2009, it is found that only company environmental responsibility information disclosure indicators are moderately positively correlated with stock price changes, while other environmental responsibility indicators are not correlated with stock price changes [55]. Our conclusion is very much similar to this research result.

Table 4. Moderating effects of high pollution companies on green CSR and company financing costs.

\begin{tabular}{|c|c|c|c|}
\hline & (1) & (2) & (3) \\
\hline & COD & COD & COD \\
\hline Env & $\begin{array}{c}-0.051 \text { *** } \\
(-3.701)\end{array}$ & & \\
\hline Env_con & & $\begin{array}{c}-0.063 \\
(-0.483)\end{array}$ & \\
\hline $\mathrm{dEnv}$ & & & $\begin{array}{c}-0.052^{* * *} \\
(-3.751)\end{array}$ \\
\hline c.Env\#c.high & $\begin{array}{c}0.121^{* * *} \\
(5.698)\end{array}$ & & \\
\hline c.Env_con\#c.high & & $\begin{array}{c}0.209 \\
(1.520)\end{array}$ & \\
\hline c.dEnv\#c.high & & & $\begin{array}{c}0.109 * * * \\
(5.071)\end{array}$ \\
\hline high & $\begin{array}{c}0.325^{* * *} \\
(3.870)\end{array}$ & $\begin{array}{l}0.620^{* * *} \\
(11.177)\end{array}$ & $\begin{array}{c}0.388^{* * *} \\
(4.907)\end{array}$ \\
\hline size & $\begin{array}{c}-0.047^{* * * *} \\
(-2.710)\end{array}$ & $\begin{array}{c}-0.053^{* * * *} \\
(-3.074)\end{array}$ & $\begin{array}{c}-0.044^{* *} \\
(-2.518)\end{array}$ \\
\hline lev & $\begin{array}{l}2.140 * * * \\
(16.156)\end{array}$ & $\begin{array}{l}2.133^{* * *} \\
(16.053)\end{array}$ & $\begin{array}{l}2.144^{* * *} \\
(16.173)\end{array}$ \\
\hline roa & $\begin{array}{l}-5.573^{* * *} \\
(-14.340)\end{array}$ & $\begin{array}{l}-5.516^{* * *} \\
(-14.163)\end{array}$ & $\begin{array}{l}-5.602 * * * \\
(-14.398)\end{array}$ \\
\hline first & $\begin{array}{c}-0.011^{* * * *} \\
(-8.560)\end{array}$ & $\begin{array}{c}-0.010^{* * *} \\
(-8.343)\end{array}$ & $\begin{array}{c}-0.011^{* * *} \\
(-8.551)\end{array}$ \\
\hline indp & $\begin{array}{c}0.785^{* *} \\
(2.450)\end{array}$ & $\begin{array}{c}0.809 * * \\
(2.518)\end{array}$ & $\begin{array}{c}0.771 \text { ** } \\
(2.406)\end{array}$ \\
\hline dual & $\begin{array}{c}0.245^{* * *} \\
(5.084)\end{array}$ & $\begin{array}{c}0.253 * * * \\
(5.260)\end{array}$ & $\begin{array}{c}0.243^{* * *} \\
(5.045)\end{array}$ \\
\hline age & $\begin{array}{c}0.004 \\
(1.054)\end{array}$ & $\begin{array}{c}0.003 \\
(0.811)\end{array}$ & $\begin{array}{c}0.004 \\
(0.967)\end{array}$ \\
\hline Industry fixed effects & $\mathrm{Y}$ & $\mathrm{Y}$ & $\mathrm{Y}$ \\
\hline Year fixed effects & $\mathrm{Y}$ & $\mathrm{Y}$ & $\mathrm{Y}$ \\
\hline _cons & $\begin{array}{c}3.520 * * * \\
(5.761)\end{array}$ & $\begin{array}{c}3.516^{* * * *} \\
(5.769)\end{array}$ & $\begin{array}{c}3.444^{* * *} \\
(5.633)\end{array}$ \\
\hline$N$ & 5360 & 5360 & 5360 \\
\hline r2_a & 0.311 & 0.308 & 0.311 \\
\hline $\mathrm{F}$ & 76.149 & 73.795 & 75.134 \\
\hline
\end{tabular}


The products of high pollution index High with the green CSR behavior (Env), Env * High, and with net value of the green social responsibility behavior (dEnv), dEnv * High are all significantly corelated under at $1 \%$ level, which reflects that the company's high pollution industry features have a moderating effect on green CSR behavior and the cost of financings. That is to say, when companies belong to high pollution industries, the moderating effect between the company's green social responsibility behavior and the financings cost savings will be significantly weakened. However, this result is mainly influenced by the characteristics of the industries, as the extent to which the high pollution industries actively undertake green social responsibility is limited, and the effectiveness of the green CSR behavior of the highly pollution industries on the reduction of financing cost is limited.

\subsection{Empirical Results and Analysis: The Moderating Effects of State-Owned Companies}

There is a close relationship between state-owned companies and the government. Studies have shown that state-owned companies take more policy burdens, and there is a strong political connection between state-owned companies and the government [56-58]. The government has a direct impact on the operation of state-owned companies. In order to compare the impact of green CSR on company financing cost between state-owned companies and private companies, the variable SOE is used in this paper to distinguish the property rights of companies. SOE for state-owned companies is 1 , for non-state-owned companies is 0 . The regression results obtained are shown in Table 5.

Table 5. Moderating effects of state-owned companies on green CSR and company financing costs.

\begin{tabular}{|c|c|c|c|}
\hline & (1) & (2) & (3) \\
\hline & COD & COD & COD \\
\hline Env & $\begin{array}{c}-0.022 \\
(-1.269)\end{array}$ & & \\
\hline Env_con & & $\begin{array}{c}0.267^{* * *} \\
(3.712)\end{array}$ & \\
\hline dEnv & & & $\begin{array}{l}-0.035 \text { ** } \\
(-1.995)\end{array}$ \\
\hline soe & $\begin{array}{c}-0.424^{* * *} \\
(-5.553)\end{array}$ & $\begin{array}{c}-0.360 * * * \\
(-7.956)\end{array}$ & $\begin{array}{c}-0.370 * * * \\
(-5.016)\end{array}$ \\
\hline c.Env\#c.soe & $\begin{array}{c}0.045^{* *} \\
(2.081)\end{array}$ & & \\
\hline c.Env_con\#c.soe & & $\begin{array}{c}0.239 * * * \\
(2.787)\end{array}$ & \\
\hline c.dEnv\#c.soe & & & $\begin{array}{c}0.027 \\
(1.250)\end{array}$ \\
\hline size & $\begin{array}{c}-0.026 \\
(-1.449)\end{array}$ & $\begin{array}{l}-0.035^{* *} \\
(-2.022)\end{array}$ & $\begin{array}{c}-0.018 \\
(-0.997)\end{array}$ \\
\hline lev & $\begin{array}{l}2.241^{* * *} \\
(16.760)\end{array}$ & $\begin{array}{l}2.183^{* * *} \\
(16.334)\end{array}$ & $\begin{array}{l}2.235^{* * *} \\
(16.705)\end{array}$ \\
\hline roa & $\begin{array}{c}-6.177^{* * *} \\
(-15.471)\end{array}$ & $\begin{array}{l}-5.913^{* * *} \\
(-14.821)\end{array}$ & $\begin{array}{c}-6.158^{* * * *} \\
(-15.406)\end{array}$ \\
\hline first & $\begin{array}{c}-0.007^{* * *} \\
(-5.296)\end{array}$ & $\begin{array}{c}-0.007^{* * *} \\
(-5.254)\end{array}$ & $\begin{array}{c}-0.007^{* * *} \\
(-5.256)\end{array}$ \\
\hline indp & $\begin{array}{l}0.546^{*} \\
(1.704)\end{array}$ & $\begin{array}{c}0.657^{* *} \\
(2.049)\end{array}$ & $\begin{array}{l}0.541 * \\
(1.691)\end{array}$ \\
\hline dual & $\begin{array}{c}0.174^{* * *} \\
(3.570)\end{array}$ & $\begin{array}{c}0.181^{* * *} \\
(3.697)\end{array}$ & $\begin{array}{c}0.173^{* * *} \\
(3.550)\end{array}$ \\
\hline age & $\begin{array}{c}0.011^{* * *} \\
(2.772)\end{array}$ & $\begin{array}{c}0.012 * * * \\
(3.024)\end{array}$ & $\begin{array}{c}0.011^{* * *} \\
(2.864)\end{array}$ \\
\hline Industry fixed effects & $\mathrm{Y}$ & Y & $\mathrm{Y}$ \\
\hline Year fixed effects & Y & Y & Y \\
\hline _cons & $\begin{array}{c}3.093 * * * \\
(4.795)\end{array}$ & $\begin{array}{c}3.219^{* * *} \\
(5.189)\end{array}$ & $\begin{array}{c}2.912 * * * \\
(4.555)\end{array}$ \\
\hline$N$ & 5360 & 5360 & 5360 \\
\hline r2_a & 0.286 & 0.297 & 0.286 \\
\hline$\overline{\mathrm{F}}$ & 68.732 & 72.135 & 68.464 \\
\hline
\end{tabular}

Note: ${ }^{* * *}, * * *$ represent $p<0.01, p<0.05, p<0.1$, respectively. 
From the three models in Table 5, we can find that the coefficient of SOE is significantly negative at the significance level of $1 \%$, which indicates that the state-owned companies have advantages in obtaining low-cost credit in China. The coefficient of the item Env_con * SOE is significantly negative at the significance level of $1 \%$, which reflects that state-owned companies are particularly sensitive to environmental punishment. That means that COD significantly increases when there is negative green CSR (Env_con), which is also consistent with Table 3 for the main regression model. This paper demonstrates that the result is determined by the present situation of state-owned companies in China and the relationship between state-owned companies and government. On the one hand, the development trend of state-owned companies to a large extent reflects the orientation of national policy; the public tends to think that state-owned companies should perform well in the green social responsibility. On the other hand, the government, on the basis of "love of father", with soft budget and policy benefits for state-owned companies, often results in state-owned companies having a low cost of financing. Therefore, when state-owned companies take green social responsibility, with the variables of the positive green CSR behavior (Env) and the net value of green CSR behavior (dEnv), the cost of financing is not significantly reduced. However, when state-owned companies are punished for environment pollution, the financing cost will significantly increase. This is because the behavior of state-owned companies can reflect the government's policy guidance and development requirements. Therefore, whether state-owned companies can set an example to take on green social responsibility is very important to the public and their own development. When state-owned companies inflict serious damage to the environment, the public will quickly have a great negative sentiment toward their behaviors, and those state-owned companies will need to pay a large cost to make up for it. At the same time, the government will take punitive measures such as reducing policy benefits, resulting in a significant increase in the cost of financing. In addition, state-owned companies have different governance structures from private companies. Although state-owned companies have problems such as lack of owners, their actual controllers tend to be government officers. When the environment evaluation system is not perfect and lags behind, the state-owned companies' leaders are more sensitive to punishment. So, the officials in state-owned companies often operate under the assumption that "no mistake is better than success", which also explains why state-owned companies taking more green responsibility have no significant effect on the financing costs, while in case of negative green CSR behavior (Env_con) the financing costs can increase. Further analysis on the total sample shows that among the 5360 companies, there are 3066 state-owned companies and 2294 private companies. Therefore, state-owned companies account for $74.82 \%$ of the total sample, which also affects the impact of positive green CSR (Env) on financing cost in the main regression to some extent.

Unlike state-owned companies, private companies do not have such stable and low-risk financing sources such as state capital, so whether they can obtain continuous and low-cost financing is very important for their survival and development. On the one hand, the higher the fulfillment degree of green social responsibility for private companies, the more favorable it is for them to get loans, and the fulfillment of company social responsibility can help companies establish political connections [59]. On the other hand, company social responsibility has a significant impact on the idiosyncratic risk of companies, and negative company social responsibility increases the risk. The higher the risk, the higher the rate of return on risk required by company investors, and thus, the financing cost of companies will rise further. The active fulfillment of social responsibility can reduce risks and financing costs [31]. Therefore, for private companies, the better the performance of green social responsibility, the higher the market and government recognition, thus resulting in reduced financing costs. On the contrary, negative green social responsibility will lead to the increase of financing cost for private companies. Therefore, private companies are fully in line with our assumptions. Both the positive green CSR behavior (Env) and the net value of green CSR behavior (dEnv) can significantly reduce the financing cost of companies, and negative green CSR (Env_con) significantly improves COD. This also shows that private companies rely less on the relationship with government departments to reduce the cost of financing. 


\subsection{Robustness Test}

In order to test the robustness of empirical results, this paper changes the measurement method of COD. COD1 equals to (interest expense + capitalized interest expense)/average debt of beginning and ending, CODF considers a lagged period of 1 year, and the regression results remain unchanged, indicating that the regression results are stable and reliable. The specific robustness test results are shown in Table 6.

Table 6. Robustness test.

\begin{tabular}{ccccccc}
\hline & $\mathbf{( 1 )}$ & $\mathbf{( 2 )}$ & $\mathbf{( 3 )}$ & $\mathbf{( 4 )}$ & $\mathbf{( 5 )}$ & $\mathbf{( 6 )}$ \\
\hline Env & COD1 & COD1 & COD1 & F.COD & F.COD & F.COD \\
\hline Env_con & -0.000 & & & -0.003 & & \\
& $(-0.012)$ & & & $(-0.231)$ & & \\
dEnv & & $0.383^{* * *}$ & & & $0.412^{* * *}$ & \\
& & $(7.714)$ & & & $(7.324)$ & \\
size & & & $-0.021^{*}$ & & & $-0.024^{*}$ \\
& -0.002 & -0.013 & $(-1.759)$ & & & $(-1.928)$ \\
lev & $(-0.125)$ & $(-0.679)$ & $(0.242)$ & $(-1.235)$ & $(-1.995)$ & $(-0.018$ \\
& $2.150^{* * *}$ & $2.112^{* * *}$ & $2.145^{* * *}$ & $2.151^{* * *}$ & $2.116^{* * *}$ & $2.143^{* * *}$ \\
roa & $(15.220)$ & $(14.975)$ & $(15.179)$ & $(14.291)$ & $(14.106)$ & $(14.222)$ \\
& $-6.075^{* * *}$ & $-5.822^{* * *}$ & $-6.053^{* * *}$ & $-5.967^{* * *}$ & $-5.565^{* * *}$ & $-5.956^{* * *}$ \\
first & $(-14.788)$ & $(-14.181)$ & $(-14.722)$ & $(-13.641)$ & $(-12.682)$ & $(-13.612)$ \\
& $-0.009^{* * *}$ & $-0.009^{* * *}$ & $-0.009^{* * *}$ & $-0.009^{* * *}$ & $-0.009^{* * *}$ & $-0.009^{* * *}$ \\
indp & $(-6.803)$ & $(-6.860)$ & $(-6.791)$ & $(-6.893)$ & $(-6.897)$ & $(-6.864)$ \\
& $0.636^{*}$ & $0.712^{* * *}$ & $0.621^{*}$ & $0.838^{* *}$ & $0.932^{* * *}$ & $0.818^{* * *}$ \\
dual & $(1.817)$ & $(2.031)$ & $(1.776)$ & $(2.342)$ & $(2.605)$ & $(2.293)$ \\
& $0.268^{* * *}$ & $0.277^{* * *}$ & $0.267^{* * *}$ & $0.324^{* * *}$ & $0.336^{* * *}$ & $0.323^{* * *}$ \\
age & $(5.225)$ & $(5.367)$ & $(5.205)$ & $(6.040)$ & $(6.222)$ & $(6.035)$ \\
& 0.004 & 0.005 & 0.005 & 0.002 & 0.003 & 0.003 \\
Industry fixed effects & $(1.073)$ & $(1.270)$ & $(1.134)$ & $(0.526)$ & $(0.782)$ & $(0.589)$ \\
Year fixed effects & $\mathrm{Y}$ & $\mathrm{Y}$ & $\mathrm{Y}$ & $\mathrm{Y}$ & $\mathrm{Y}$ & $\mathrm{Y}$ \\
_cons & $\mathrm{Y}$ & $\mathrm{Y}$ & $\mathrm{Y}$ & $\mathrm{Y}$ & $\mathrm{Y}$ & $\mathrm{Y}$ \\
& $2.528^{* * *}$ & $2.742^{* * *}$ & $2.406^{* * *}$ & $2.303^{* *}$ & $2.494^{* * *}$ & $2.195^{* *}$ \\
& $(3.876)$ & $(4.340)$ & $(3.714)$ & $(2.299)$ & $(2.612)$ & $(2.215)$ \\
\hline$N$ & 5360 & 5360 & 5360 & 4289 & 4289 & 4289 \\
r2_a & 0.254 & 0.261 & 0.254 & 0.277 & 0.286 & 0.277 \\
F & 67.500 & 70.417 & 67.370 & 62.880 & 66.579 & 61.527 \\
\hline
\end{tabular}

Note: $* * * * * * *$ represent $p<0.01, p<0.05, p<0.1$, respectively. COD1 $=$ (interest expense + capitalized interest expense)/average debt of the beginning and ending. CODF $=$ Interest expense $t+1 * 100 /\left(\right.$ initial debt $_{t+1}+$ ending $\left.\operatorname{debt}_{\mathrm{t}+1}\right) / 2$.

\section{Conclusions}

The impact of CSR fulfillment on financing cost has become one of the research hotspots in the academic world in recent years. This paper takes Chinese A-share listed companies in Shanghai and Shenzhen Stock Exchanges from 2007 to 2018 as research samples, by means of moderating effect and multiple regression analysis, and builds the relationship between green CSR and company financing cost. The results indicate that the better the performance of companies' green social responsibility, the more financing cost of companies can be significantly reduced. In other words, companies' green social responsibility has a significant saving effect on financing cost. Further study indicates that high pollution characteristics and nature of property rights can adjust the green CSR's influence on financing costs. For companies with different pollution degrees and nature of property rights, the green CSR's saving effect on financing costs is different. Compared with low polluting companies, high-polluting companies will have a weakened saving effect of green CSR on financing cost due to their industry characteristics and external financing constraints. Compared with private companies, state-owned companies have the advantages of "political nature" and "national representativeness", which will also weaken the role of green CSR in reducing financing costs. The research conclusions of this paper can encourage companies to actively undertake green social responsibility, improve environmental quality, and reduce the cost of company financing. 
The contribution of this paper is that it expands and enriches the theoretical research on green CSR and financial cost. Most of the previous studies look at these two aspects separately. This paper provides a new perspective for studying the impact of green CSR on financial cost. It proves the positive effect of green CSR on company financial costs. To a certain extent, it has dual functions; first of all, reducing company financial costs, and encouraging companies to actively undertake green CSR as a tool to achieve both economic benefits and ecological benefits. In other words, companies that spend more on green CSR can generate many benefits, such as energy conservation, to build a green reputation and therefore get more financial support. What is more, this will bring lots of new opportunities and economic growth points, which can promote the development of green transformation system and also be good for enterprises.

There are two possible limitations of this study that must be acknowledged. First, today, with the development of the Chinese Government Green Credit program, green credit will be a driving item of enterprises, which means the green credit program may be an important potential mechanism of energy conservation. However, due to limitation of available data, it is hard to lift analysis from theoretical level, and there is no empirical analysis carried out based on the credit score and loan amount obtained by listed companies. Second, it is hard to defined green CS because it is a new concept in China. We measured green CSR by three dimensions, including different items, which are collected manually. However, the limitations of this paper can be overcome by the development of Chinese Government Green Credit program, which will bring much more reliable and available data. Therefore, the paper also leaves much room for future research.

Author Contributions: Conceptualization, D.J. and L.Z.; methodology, Y.L.; software, D.J. and Y.L.; formal analysis, D.J., L.Z. and Y.L.; investigation, J.A. and W.S.; resources, L.Z., J.A. and W.S.; data curation, Y.L.; writing-original draft preparation, D.J. and Y.L.; writing—review and editing, L.Z., J.A. and W.S.; project administration, L.Z. All authors have read and agreed to the published version of the manuscript.

Funding: This study was supported by the Fujian Philosophy and Social Science Fund (Grant No. FJ2018MGCA005), Youth project of National Natural Science Foundation of China (Grant No. 71902098), Youth Project of Social Science Planning Project of Shandong Province (Grant No. 20DGLJ07), and Ji'nan Philosophy and Social Science Planning Key Project (Grant No. JN19B29).

Conflicts of Interest: The authors declare no conflict of interest.

\section{References}

1. Hsu, F.J. Does corporate social responsibility extend firm life-cycles? Manag. Decis. 2018, 56, $2408-2436$. [CrossRef]

2. McWilliams, A.; Siegel, D. Corporate social responsibility: A theory of the firm perspective. Acad. Manag. Rev. 2001, 26, 117-127. [CrossRef]

3. Malik, M. Value-Enhancing Capabilities of CSR: A Brief Review of Contemporary Literature. J. Bus. Ethics 2015, 127, 419-438. [CrossRef]

4. Hang, S.; Zhao, C.; Zeng, J. Can environmental management improve financial performance: An empirical study of A-shares listed companies in China. J. Clean. Prod. 2017, 141, 1051-1056.

5. Ji, Q.; Zhang, D. How much does financial development contribute to renewable energy growth and upgrading of energy structure in China? Energy Policy 2019, 128, 114-124. [CrossRef]

6. Zisopoulou, K.; Panagoulia, D.G. Solar Power: A new mathematical definition and theoretical proof it is a Green Public Good. J. Space Weather Space Clim. 2019, 1, 312-327. [CrossRef]

7. Ye, L.; Zhang, J. Green Social Responsibility of Companies. Oper. Manag. 2010, 1, 48-49.

8. Tsai, S.-b.; Chien, M.-F.; Xue, Y.; Li, L.; Jiang, X.; Chen, Q.; Zhou, J.; Wang, L. Using the Fuzzy DEMATEL to Determine Environmental Performance: A Case of Printed Circuit Board Industry in Taiwan. PLoS ONE 2015, 10, e0129153. [CrossRef]

9. Wu, G. Company Green Social Responsibility. J. China Univ. Geosci. (Soc. Sci. Ed.) 2005, 5, 24-30.

10. "Company social responsibility in green development in China" policy research project group of the national cooperation council. Company social responsibility in green development in China. Environ. Sustain. Dev. 2014, 39, 74-87. 
11. Zhan, Y.; Wen, G. Analysis of financing status of small and Medium-sized Companies. China Commer. Trade 2011, 6, 99-100.

12. Luke, A.; Imoh, I.-I.; Mina, M.O. Exploring Knowledge Management and Green Corporate Strategy (GCS) Nexus. Int. J. Soc. Sci. Humanit. Res. 2016, 4, 66-82.

13. Kalomoira, Z.; Sofia, K.; Maria-Eleni, K.; George, P.; Euaggelos, K.; Antonios, K.; Emmanuella, T.; Dionysia, P. Recasting of the WEF Nexus as an actor with a new economic platform and management model. Energy Policy 2018, 119, 123-139.

14. Porter, M.E.; Linde, C.v.d. Green and Competitive. Harv. Bus. Rev. 1995, 28, 128-129. [CrossRef]

15. Porter, M.E.; Linde, C.v.d. Toward a New Conception of the Environment-Competitiveness Relationship. J. Econ. Perspect. 1995, 9, 97-118. [CrossRef]

16. Jiang, J. Company Green Responsibility in the Context of Environmental Ethics. Learn. Explor. 2013, 11, 91-95.

17. Song, J. Green Social Responsibility of Companies. Chin. Foreign Entrep. 2019, 33, 52.

18. Wu, W.; Liu, Y.; Chin, T.; Zhu, W. Will Green CSR Enhance Innovation? A Perspective of Public Visibility and Firm Transparency. Int. J. Environ. Res. Public Health 2018, 15, 268. [CrossRef]

19. Darnall, N.; Henriques, I.; Sadorsky, P. Do environmental management systems improve business performance in an international setting? J. Int. Manag. 2007, 14, 364-376. [CrossRef]

20. Abbas, J. Impact of total quality management on corporate green performance through the mediating role of corporate social responsibility. J. Clean. Prod. 2020, 242. [CrossRef]

21. Yeli, C. Company Green Social Responsibility. Consum. Guide 2008, 6, 108.

22. Guenster, N.; Bauer, R.; Derwall, J. The Economic Value of Corporate Eco-Efficiency. Eur. Financ. Manag. 2011, 4, 619-704. [CrossRef]

23. Green, T.; Peloza, J. How does corporate social responsibility create value for consumers? J. Consum. Mark. 2011, 28, 48-56. [CrossRef]

24. Dhaliwal, D.S.; Radhakrishnan, S.; Tsang, A.; Yang, Y.G. Nonfinancial Disclosure and Analyst Forecast Accuracy: International Evidence on Corporate Social Responsibility Disclosure. Account. Rev. 2012, 87, 723-759. [CrossRef]

25. Naughton, J.P.; Wang, C.; Yeung, I. Investor Sentiment for Corporate Social Performance. Account. Rev. 2018, 94, 401-420. [CrossRef]

26. Lonka, K.; Lindblom-YlÄnne, S.; Maury, S. The effect of study strategies on learning from text. Pergamon 1994, 4, 253-271. [CrossRef]

27. Chollet, P.; Sandwidi, B.W. CSR engagement and financial risk: A virtuous circle? International evidence. Glob. Financ. J. 2018, 38, 65-81. [CrossRef]

28. Sengupta, P. Corporate Disclosure Quality and the Cost of Debt. Account. Rev. 1998, 73, 459-474.

29. Yu, F.; Zhang, M. Quality of Information Disclosure and Financing Cost - Empirical evidence from China's Securities market. Audit Econ. Res. 2007, 5, 93-96.

30. Sanjeev, B.; Partha, S. SSRN-Effect of Corporate Governance on Bond Ratings and Yields: The Role of Institutional Investors and Outside Directors. J. Bus. 2003, 76, 455-476.

31. La Rosa, F.; Liberatore, G.; Mazzi, F.; Terzani, S. The impact of corporate social performance on the cost of debt and access to debt financing for listed European non-financial firms. Eur. Manag. J. 2018, 36, 519-529. [CrossRef]

32. Dengjin, Z.; Tianyi, Y. Accounting conservatism, Audit Quality and Financing Cost. Audit Res. 2016, 2, 74-81.

33. Yiming, H.; Shilei, X. Bank supervision effect and loan pricing - an empirical study from listed companies. Manag. World 2005, 5, 27-36.

34. Sreedhar, T.; Bharath, J.S.; Shyam, V.S. Accounting Quality and Debt Contracting. Account. Rev. 2008, 83, $1-28$.

35. Jung, J.; Herbohn, K.; Clarkson, P.; Carbon, R. Carbon Risk Awareness and the Cost of Debt Financing. J. Bus. Ethics 2018, 150, 1151-1171. [CrossRef]

36. Changkui, L.; Jiya, B. Influence of carbon disclosure quality on company financing cost under external governance. J. Donahue Univ. (Nat. Sci. Ed.) 2020, 46, 321-327.

37. Clark, C.E.; Steckler, E.; Newell, S. Managing Contradiction: Stockholder and Stakeholder Views of the Firm as Paradoxical Opportunity. Bus. Soc. Rev. 2016, 121, 123-159. [CrossRef]

38. Andrei, S.; Vishny, R.W. A Survey of Company Governance. J. Financ. 1997, 52, 737-783. 
39. Cui, W. Company Governance and Financing Cost-Empirical Evidence from A-share listed companies in Shenzhen Stock Exchange. Financ. Account. Commun. 2008, 1, 73-76.

40. Longstaff, F.A.; Mithal, S.; Neis, E. Corporate Yield Spreads: Default Risk or Liquidity? New Evidence from the Credit Default Swap Market. J. Financ. 2005, 60, 2213-2253. [CrossRef]

41. Chen, L.; Lesmond, D.A.; Wei, J. Corporate Yield Spreads and Bond Liquidity. J. Financ. 2007, 62, 119-149. [CrossRef]

42. Gatev, E.; Strahan, P.E. Liquidity risk and syndicate structure. J. Financ. Econ. 2008, 93, 490-504. [CrossRef]

43. He, Y.; Tang, Q.; Wang, K. Carbon Information Disclosure, Carbon Performance and Capital Cost. Acc. Res. 2014, 1, 79-86.

44. Clarkson, P.M.; Li, Y.; Richardson, G.D.; Vasvari, F.P. Revisiting the relation between environmental performance and environmental disclosure: An empirical analysis. Acc. Organ. Soc. 2007, 33, 303-327. [CrossRef]

45. Mishra, S.; Modi, S.B. Positive and Negative Corporate Social Responsibility, Financial Leverage, and Idiosyncratic Risk. J. Bus. Ethics 2013, 117, 431-448. [CrossRef]

46. Zhou, Z.; Wen, K.; Zeng, H. Carbon risk, media attention and financing cost-empirical evidence from listed companies in China's A-share high-carbon industry. Mod. Financ. Econ. (J. Tianjin Univ. Financ. Econ.) 2017, $37,16-32$.

47. Claessens, S.; Laeven, L. What Drives Bank Competition? Some International Evidence. J. Money Credit Bank. 2004, 36, 563-583. [CrossRef]

48. Wang, B. Green Credit, Company Social responsibility disclosure and Financing Cost-Based on the Empirical Study of heavily polluting A-share listed companies from 2011 to 2017. Financ. Theory Pract. 2019, 7, 47-54.

49. Giuli, A.D.; Kostovetsky, L. Are red or blue companies more likely to go green? Politics and corporate social responsibility. J. Financ. Econ. 2014, 111, 158-180. [CrossRef]

50. Khwaja, A.I.; Mian, A. Tracing the Impact of Bank Liquidity Shocks: Evidence from an Emerging Market. Am. Econ. Rev. 2008, 98, 1413-1442. [CrossRef]

51. Charumilind, C.; Kali, R.; Wiwattanakantang, Y. Connected Lending: Thailand before the Financial Crisis. J. Bus. 2006, 79, 181-218. [CrossRef]

52. Leuz, C.; Oberholzer-Gee, F. Political relationships, global financing, and corporate transparency: Evidence from Indonesia. J. Financ. Econ. 2005, 81, 411-439. [CrossRef]

53. Brandt, L.; Li, H. Bank Discrimination in Transition Economies: Ideology, Information or Incentives? William Davidson Inst. Work. Pap. Ser. 2002, 31, 387-413.

54. Cheng, J.; Liu, Y. The effects of public attention on the environmental performance of high-polluting firms: Based on big data from web search in China. J. Clean. Prod. 2018, 186, 335-341. [CrossRef]

55. Gong, Q. Research on the Correlation between Environmental Responsibility Fulfillment and Stock Price of China's Heavily Pollution Listed Companies; Southwest Communication University: Chengdu, China, 2011.

56. Fan, J.P.H.; Wong, T.J.; Zhang, T. Politically connected CEOs, corporate governance, and Post-IPO performance of China's newly partially privatized firms. J. Appl. Corp. Financ. 2014, 26, 85-95. [CrossRef]

57. Luo, D.; Tang, Q. Research on regulation context and performance issue of China's private listed companies. Econ. Res. 2009, 44, 106-118.

58. Yu, M.; Hui, Y.; Pan, H. Political connection, rent-seeking and effectiveness of local government financial subsidies. Econ. Res. 2010, 45, 65-77.

59. Li, S.; Xie, X. Social responsibility, political connection and debt financing of private companies - empirical evidence from China's capital market. Nankai Manag. Rev. 2014, 17, 30-40.

(C) 2020 by the authors. Licensee MDPI, Basel, Switzerland. This article is an open access article distributed under the terms and conditions of the Creative Commons Attribution (CC BY) license (http://creativecommons.org/licenses/by/4.0/). 